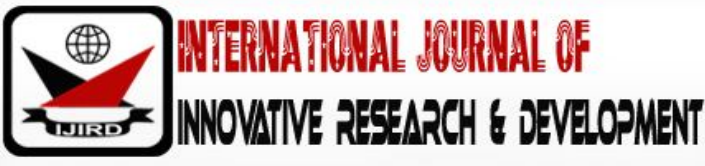

ISSN 2278 - 0211 (Online)

\section{Metal Concentrations of Water and Food Cooked in Various Cooking Pots}

\author{
Onyeka E.U \\ Professor, Department of Food Science and Technology, Federal University of Technology, Nigeria \\ Ibeawuchi 0.0 \\ Research Student, Department of Food Science and Technology, Federal University of Technology, Nigeria
}

\begin{abstract}
:
Migration of heavy metals from cooking pots into water and food during cooking was investigated. Five foodstuffs and nine cooking pots were used. Water was boiled for $6 \mathrm{~m}$ while the various foodstuffs were cooked for varying lengths of time to doneness. Seven metals, namely Aluminum, Arsenic, Mercury, Lead, Cupper, Iron and Nickel were determined using spectrophotometer. The metal content of boiled water was significantly $(\mathrm{p}<0.05)$ higher than the unboiled water. Metal migration from the pots increased $(\mathrm{p}=0.05)$ when sodium bicarbonate was introduced to the boiling water $(\mathrm{pH} 10.5)$. Migration of metals from pot into the cooking substances was lowest in Titanium steel cooking pot followed by enamel pot and lastly by Aluminum pot. We discovered that generally cooked food samples had higher content of the metal elements compared to control samples, confirming that cooking pots can leach trace metals into food during cooking/processing depending on the materials they are forged with. Aluminum pots leached the highest quantity of Al ions, with the older pot leaching more $(0.98 \mathrm{mg} / \mathrm{L})$ than the new one $(0.56 \mathrm{mg} / \mathrm{L})$ in boiled water extracts. The metals observed to have migrated from some pots at levels exceeding the standard limits were Al, Ni and Fe ions. Other leachates such as arsenic, mercury, lead and copper from the various pots were negligible. Some of the pots maintained a pattern of metal leaching irrespective of the food they were used to cook while others were affected by food type. Our work has demonstrated that the problem of metal leaching is more or less arising from the pot; though food type affected their leaching. Our results support the need to regulate the quality materials used to manufacture cooking pots.
\end{abstract}

Keywords: cooking pot, leachates, trace metals, food, tolerable limits

\section{Introduction}

Most cooking pots are made of metals at different ratio combinations and can melt under heat and can corrode under extreme pH (Greger, 1985, Waskonli, 2009; Maurice, 2011, Weidenhamer, et al 2014 Rocz Panstw Zakl Hig. 2014; Stahl T, Falk $\underline{\mathrm{S}}$ Rohrbeck A, et al 2017). Hence the assertion that metals used in forging cooking pots may seep into food during food preparation and subsequently to human body (Ranau R, et al, 2001, Verissimo et al, 2006, Waskonli, 2009). The awareness of the dangers of metals from cooking utensil is therefore of growing concern to public health given that food contaminants induced by cooking pots are most likely to be taken along with the food because cooking is located at the end of the chain of food preparation (WHO. 2001; Shelton et al, 2003; Karbouji, 2007; Stahl et al. 2011, Mohammad et al, 2011; Kurtus, 2012; Kamerud et al, 2013,). A naturally nutrient-dense food can be turned on its head to become poison-dense through wrong handling or preparation. Several factors including the cooking utensils influence the changes associated with food during cooking (Greger, 1985; Cheng and Brittin, 1991, Rose 2015, Alice et al 2015).

Although information on the possibility of metal leaching from cook wares has gained great interest in recent times, the leaching of metals into food from food contact surfaces is not covered by the occurrence dataset used to estimate metal dietary exposure (WHO, 2001). Secondly, previous researches conducted on the release of metals from cooking utensils during food processing procedures are usually simulated. Often the pots were tested using non-food matrixes like single chemical component acidic solution. Acidic solutions such as acetic acids may not be sufficiently similar to acidic foods which are made up of a complex array of chemistries such as citrate, oxalate, tartrate, etc. Hence this research was channeled to evaluate the metal leaching capabilities of some cooking pots. In this study, we assessed and compared the concentrations of Aluminum, nickel, mercury, arsenic, iron, lead, and copper in both boiled water and various foods. Further, we estimated the level of human health risk associated with the consumption of food cooked in different cooking pot by determining the 
Estimated Daily Intake (EDI) of metals from each cooking pot. Consequently, we proposed that the prolonged cooking of food in alumimiun pot, clay pots, and cast-iron pots would be associated with a higher human health risk than Titanium steel, stainless steel and enamel pots. The significance of this information to the food safety and security can generally not be overemphasized.

\subsection{Problem Addressed}

- Information on the possibility of metal leaching from cooking pot has gained great interest but less information has been reported on monitoring their presence in processed/ cooked food.

- Previous researches conducted on the release of metals from cook wares during food processing procedures are usually stimulated.

\subsection{AIMS}

- To determine the metal leaching/ sleeping capability of different cooking pots during cooking.

\section{Materials and Methods}

\subsection{Cooking Pot Procurement and Collection}

Cooking pots namely Clay (Earthen), Cast iron, Enamel, Stainless and Aluminum pots utilized for this study were purchased from Relief market in Owerri, Imo state, Nigeria. Titanium (Clad) pot was ordered directly from a "SaladMaster" marketing distributor in Nigeria while the old Aluminum and stainless-steel pots were of known history and obtained from a family in Owerri, Nigeria. The old pots were within 2-5years old with no form of deformation.

\subsection{Cooking Pot Preparation}

Firstly, the new pots of Aluminum, Clay, Enamel, Cast Iron and Titanium were rinsed with water to remove dirts. The old pots of known history were washed with detergent and sponge and rinsed with distilled water. Finally, all the cooking pots were filled with distilled water and heated on a 4-burner top Table gas stove (Kingbright G.4-T804A) for half an hour for proper cleaning/ rinsing. The water was drained and the pots allowed to cool at room temperature prior to their being used for the experiments.

\subsection{Boiling of Water with Various Cooking Pot}

Each cooking pot was used to boil $500 \mathrm{ml}$ of water for six minutes under the same heat intensity. Two types of water were used. First was a distilled water while the second was distilled water alkalized ( $\mathrm{pH} 10.5$ ) by adding $2 \mathrm{~g}$ of sodium bicarbonate into $500 \mathrm{~mL}$ water. After boiling the water samples were cooled to room temperature and subsequently analysed for presence of metals.

\subsection{Cooking of Food Items}

The major food groups used includes vegetable, fleshy, tubers; cereals and legume were obtained from the local market. Each of the food items was divided into two portions. One portion (untreated) was analyzed raw and the other portion was used for the cooking experiment. Each foodstuff was cooked with the various pots. Generally, the heating regime given to each cooking pot was the same for each food, and enough to cook each food to doneness. Tomatoes were sorted and washed with running water to remove dirts and sliced into thickness of $10 \mathrm{~mm}$ using a sharp stainless knife. The sliced tomatoes were placed into the different pots and allowed to cook on the gas stove for $6 \mathrm{~m}$ (Dabonne et al, (2010). Five hundred grams each of rice and brown beans (Oloyin) were cleaned to remove stones and other unwanted grains. The cleaned grains were each washed with portable water and cooked differently in the various cooking pots with equal volume of distilled water and heat intensity. The rice was cooked for $40 \mathrm{~m}$ while brown beans was cooked for $70 \mathrm{~min}$ as advised by the local consumers. One medium sized white yam was cleaned by brushing off soil particles, manually sliced into bit sizes with stainless knife and washed. Seven sliced yam bit samples were placed on each pot and the same volume of water was added to each pot and allowed to cook on the gas stove for $45 \mathrm{~m}$. All cooked samples were drained from the pot, allowed to cool and coded for analysis.

\subsection{Determination of Metal Content}

Two grams each of the samples were weighed into Pyrex glass conical flasks. Then $10 \mathrm{ml}$ of conc. perchloric acid was introduced into the flask using a straight glass pipette. Five milliliters of nitric acid were also added in the ratio of 1:2. The mixture was swirled, placed in the fume cupboard and heated on an electro thermal heater $105{ }^{\circ} \mathrm{C}$ for $30 \mathrm{~m}$ until a clear digest was obtained. The tubes were removed from the digest, cooled to room temperature and diluted to 50ml with distilled water. The diluent was filtered into a plastic vial for Absorption Atomic Spectrophotometric (AAS) analysis. The digested solution $(1 \mathrm{~mL})$ was used to determine the following minerals, copper, iron, nickel, mercury, arsenic, lead and aluminum in both water and food samples respectively. The absorption radiation by the minerals mentioned at various wavelengths was measured using the AAS (Buck Scientific Model 200A System). The spectrophotometer was standardized using the standard solution of 
the element being analyzed and acidified deionized water was aspirated to zero the instrument. Air/ acetylene flame was used and sample extracts were aspirated and concentrations read-off the instrument (Bhat, 2010, AOAC 1990).

\subsection{Determination of Daily Metal Intake}

The calculation of daily ingestion of metal from cooked food was based on the assumption that an average adult person (70kg weight) eats $600 \mathrm{~g}$ of staple food per meal/serving. Tomato is not included as a staple food. Under normal conditions, an individual adult eats three times a day, which amounts to $1800 \mathrm{~g}$ of staple food per day. Therefore, multiplying the quantity of metal (per 100g) by the quantity of food consumed per day we get an estimated value of daily metal ingestion from cooked food (Equation 1). The estimated values obtained are expected to increase when we add the metals that may come from other food ingredients such as meat and spices eaten along with the staple.

$$
\mathrm{EDMI}=(\mathrm{MC} \times \mathrm{DI}) \times \mathrm{BW}-1
$$

Where $\mathrm{MC}=$, heavy metal concentration in cooked food $\left(\mathrm{mg} \mathrm{kg}^{-1}\right.$ on wet weight basis), DI = daily average staple food intake (1800 g per person per day and BW = average body weight ( $70 \mathrm{~kg}$ per adult). Estimated Daily Intake were compared with Provisional Maximum Tolerable Daily Intake (PMTDI) [FAO/ WHO,2011, NRS 2010, EU/ EC 2015/ 2016; JECFA, 2010) as the case may be. Estimated Weekly Intake (EWI) were converted to Estimated Daily Intake (EDI) by dividing EWI by 7 (Gbogbo, et al. (2018).

\subsection{Experimental Design and Statistical Analysis}

All determinations were replicated thrice and data obtained were analyzed using analysis of variance (ANOVA) on SPSS 20 statistical software package. The data were subjected to two-way analysis of variance (ANOVA) in a 5x9 RCBD factorial design. In all the experiments means were separated using Fisher's Least Significant Difference (LSD) and significance was accepted at (5\%) probability level.

\section{Results}

The various cooking pots leached heavy metals at varying significant $(p<0.05)$ rates when they were used to boil distilled water (Table 1). Expectedly the highest iron leaching $(0.11 \mathrm{mgFe} / \mathrm{L})$ occurred in cast iron pots while aluminum pots leached the highest quantity $(0.098 \mathrm{mg} \mathrm{Al} / \mathrm{L})$ of aluminum metal. Significant $(\mathrm{p}<0.05)$ variations in Ni leachate existed in the studied cooking pots. A range of $0.012-0.34 \mu \mathrm{g}$ nickel/ $\mathrm{L}$ was recorded with the highest concentration occurring in the water sample boiled in old stainless pots. A general trend showed that old cooking pots seeped more metals than their new versions (Fig 1). The old and new versions of aluminum pots leached 0.098 and $0.086 \mathrm{mgAL} / \mathrm{L}$ respectively while old and new versions of stainless pot leached 0.32 and $0.06 \mathrm{mgNi} / \mathrm{L}$ of nickel respectively. New aluminum pot compared closely to enamel and titanium steel pots in terms of metal leaching. Statistically enamel and titanium pots did not produce leachates more than the control. None of the cooking pots leached statistically high doses of lead, mercury and arsenic compared to control sample. 


\begin{tabular}{|c|c|c|c|c|c|c|c|c|c|c|c|}
\hline \multirow{2}{*}{$\begin{array}{c}\text { Metal } \\
\text { (MTL:mg/ L) }\end{array}$} & \multirow[t]{2}{*}{ Extracts } & \multicolumn{10}{|c|}{ Cooking Pots } \\
\hline & & $\mathrm{CON}$ & $\mathrm{NA}$ & $\mathrm{CI}$ & OS & $\mathrm{OA}$ & TS & $\mathrm{OE}$ & NS & CLAY & $\mathrm{NE}$ \\
\hline \multirow[t]{2}{*}{$\mathrm{AL} / 0.2$} & Water & $\begin{array}{c}0.0010^{\mathrm{d}} \pm 0 . \\
00\end{array}$ & $\begin{array}{c}0.0042^{\mathrm{b}} \\
\pm 0.04\end{array}$ & $\begin{array}{l}0.004^{\mathrm{d}} \\
\pm 0.00\end{array}$ & $\begin{array}{c}0.006^{\mathrm{d} \pm} \\
0.00\end{array}$ & $\begin{array}{c}0.0862^{\mathrm{a}} \\
\pm 0.01\end{array}$ & $\begin{array}{l}0.0010 \\
d \pm 0.01\end{array}$ & $\begin{array}{l}0.0009 \\
\mathrm{~d} \pm 0.00\end{array}$ & $\begin{array}{c}0.0007 \mathrm{~d} \\
\pm 0.01\end{array}$ & $\begin{array}{c}0.0024^{c} \\
\pm 0.01\end{array}$ & $\begin{array}{c}0.0009 \mathrm{~d} \\
\pm 0.00\end{array}$ \\
\hline & Alkaline & $\begin{array}{c}0.0010^{\mathrm{d}} \pm 0 . \\
00\end{array}$ & $\begin{array}{c}0.0086^{b} \\
\pm 0.00\end{array}$ & $\begin{array}{l}0.014^{\mathrm{d}} \\
\pm 0.00\end{array}$ & $\begin{array}{c}0.0014^{\mathrm{d}} \\
\pm 0.01\end{array}$ & $\begin{array}{c}0.098 \mathrm{a} \pm \\
0.00\end{array}$ & $\begin{array}{l}0.0012 \\
d \pm 0.01\end{array}$ & $\begin{array}{l}0.0016 \\
\mathrm{~d} \pm 0.01\end{array}$ & $\begin{array}{c}0.0012^{\mathrm{d}} \\
\pm 0.01\end{array}$ & $\begin{array}{c}0.0046^{c} \\
\pm 0.01\end{array}$ & $\begin{array}{c}0.0016^{\mathrm{d}} \\
\pm 0.01\end{array}$ \\
\hline \multirow[t]{2}{*}{ AS/ 0.1} & Water & $\begin{array}{c}0.030 \mathrm{a} \pm 0.0 \\
1\end{array}$ & $\begin{array}{c}0.023 \mathrm{~d} \pm \\
0.00\end{array}$ & $\begin{array}{c}0.034 \mathrm{~cd} \\
\pm 0.00\end{array}$ & $\begin{array}{c}0.033^{\mathrm{cd}} \pm \\
0.00\end{array}$ & $\begin{array}{c}0.028 \mathrm{~d} \pm \\
0.00\end{array}$ & $\begin{array}{c}0.044^{\mathrm{ab}} \\
\pm 0.04\end{array}$ & $\begin{array}{c}0.040 \mathrm{bc} \\
\pm 0.01\end{array}$ & $\begin{array}{l}0.042^{\mathrm{ab}} \\
\mathrm{c} \pm 0.01\end{array}$ & $\begin{array}{c}0.040^{\mathrm{bc}} \pm \\
0.00\end{array}$ & $\begin{array}{c}0.042^{\mathrm{abc}} \\
\pm 0.01\end{array}$ \\
\hline & Alkaline & $\begin{array}{c}0.030^{\mathrm{a}} \pm 0.0 \\
1\end{array}$ & $\begin{array}{c}0.023^{\mathrm{cd}} \pm \\
0.00\end{array}$ & $\begin{array}{c}0.033^{\mathrm{cd}} \\
\pm 0.00\end{array}$ & $\begin{array}{c}0.030^{\mathrm{b}} \pm \\
0.05\end{array}$ & $\begin{array}{c}0.021 \mathrm{~d} \pm \\
0.00\end{array}$ & $\begin{array}{l}0.039 \mathrm{~b} \\
\pm 0.01\end{array}$ & $\begin{array}{l}0.037 \mathrm{~b} \\
\pm 0.01\end{array}$ & $\begin{array}{c}0.035^{\mathrm{b}} \pm \\
0.01\end{array}$ & $\begin{array}{c}0.031 \mathrm{bc} \pm \\
0.00\end{array}$ & $\begin{array}{c}0.037 \mathrm{~b} \pm \\
0.00\end{array}$ \\
\hline \multirow[t]{2}{*}{$\mathrm{Hg} / 0.001$} & Water & $\begin{array}{c}0.0350^{\mathrm{a}} \pm 0 . \\
01\end{array}$ & $\begin{array}{c}0.018^{\mathrm{d}} \pm \\
0.00\end{array}$ & $\begin{array}{c}0.014 \mathrm{~cd} \\
\pm 0.00\end{array}$ & $\begin{array}{c}0.013^{\mathrm{cd}} \pm \\
0.00\end{array}$ & $\begin{array}{c}0.018 \mathrm{~d} \pm \\
0.00\end{array}$ & $\begin{array}{c}0.024 \mathrm{ab} \\
\pm 0.04\end{array}$ & $\begin{array}{l}0.0240 \\
b c \pm 0.01\end{array}$ & $\begin{array}{l}0.022^{\mathrm{ab}} \\
\mathrm{c} \pm 0.01\end{array}$ & $\begin{array}{c}0.020^{\mathrm{bc}} \pm \\
0.00\end{array}$ & $\begin{array}{c}0.022^{\mathrm{abc}} \\
\pm 0.01\end{array}$ \\
\hline & Alkaline & $\begin{array}{c}0.030^{\mathrm{a}} \pm 0.0 \\
2\end{array}$ & $\begin{array}{c}0.015^{\mathrm{a}} \pm \\
0.01\end{array}$ & $\begin{array}{c}0.018 \mathrm{a} \pm \\
0.00\end{array}$ & $\begin{array}{c}0.022^{\mathrm{a} \pm} \\
0.01\end{array}$ & $\begin{array}{c}0.015^{\mathrm{a}} \pm \\
0.00\end{array}$ & $\begin{array}{l}0.024 \mathrm{a} \\
\pm 0.00\end{array}$ & $\begin{array}{c}0.022^{\mathrm{a}} \pm \\
0.01\end{array}$ & $\begin{array}{c}0.024 \mathrm{a} \pm \\
0.01\end{array}$ & $\begin{array}{c}0.022^{\mathrm{a} \pm} \\
0.01\end{array}$ & $\begin{array}{c}0.022^{\mathrm{a}} \pm \\
0.00\end{array}$ \\
\hline \multirow[t]{2}{*}{$\mathrm{Pb} / 0.01$} & Water & $1.16^{\mathrm{a}} \pm 0.08$ & $\begin{array}{c}1.04 \mathrm{de} \pm 0 \\
.01\end{array}$ & $\begin{array}{c}1.07 \mathrm{~cd} \pm \\
0.05\end{array}$ & $\begin{array}{c}1.10^{b c} \pm 0 \\
.10\end{array}$ & $\begin{array}{c}1.01 \mathrm{e} \pm 0 . \\
00\end{array}$ & $\begin{array}{c}1.14^{\mathrm{ab}} \pm \\
0.04\end{array}$ & $\begin{array}{c}1.12^{\mathrm{ab} \pm} \\
0.06\end{array}$ & $\begin{array}{c}1.12^{\mathrm{ab} \pm} \\
0.06\end{array}$ & $\begin{array}{c}1.10^{b c} \pm 0 \\
.06\end{array}$ & $\begin{array}{c}1.12^{\mathrm{ab}} \pm 0 \\
.02\end{array}$ \\
\hline & Alkaline & $1.16^{\mathrm{a}} \pm 0.08$ & $\begin{array}{c}1.01 \mathrm{a} \pm 0 . \\
00\end{array}$ & $\begin{array}{c}1.04 \mathrm{a} \pm 0 \\
.01\end{array}$ & $\begin{array}{c}1.07 a \pm 0 . \\
01\end{array}$ & $\begin{array}{c}0.07 \mathrm{a} \pm 0 . \\
04\end{array}$ & $\begin{array}{c}1.11 \mathrm{a} \pm \\
0.01\end{array}$ & $\begin{array}{c}1.08^{\mathrm{a}} \pm 0 \\
.04\end{array}$ & $\begin{array}{c}1.09 \mathrm{a} \pm 1 \\
.00\end{array}$ & $\begin{array}{c}1.07 a \pm 0 . \\
07\end{array}$ & $\begin{array}{c}1.09 a \pm 0 . \\
00\end{array}$ \\
\hline \multirow[t]{2}{*}{ CU/ 1.0} & Water & $\begin{array}{c}0.018^{\mathrm{a}} \pm 0.0 \\
0\end{array}$ & $\begin{array}{c}0.010^{\mathrm{a}} \pm \\
0.00\end{array}$ & $\begin{array}{c}0.013 \mathrm{a} \pm \\
0.01\end{array}$ & $\begin{array}{c}0.015^{\mathrm{a} \pm} \\
0.00\end{array}$ & $\begin{array}{c}0.010^{\mathrm{a}} \pm \\
0.00\end{array}$ & $\begin{array}{c}0.018^{\mathrm{a}} \\
\pm 0.01\end{array}$ & $\begin{array}{c}0.015^{\mathrm{a} \pm} \\
0.00\end{array}$ & $\begin{array}{c}0.015^{\mathrm{a} \pm} \\
0.00\end{array}$ & $\begin{array}{c}0.013 \mathrm{a} \pm \\
0.00\end{array}$ & $\begin{array}{c}0.015^{\mathrm{a}} \pm \\
0.01\end{array}$ \\
\hline & Alkaline & $\begin{array}{c}0.018^{\mathrm{a}} \pm 0.0 \\
0\end{array}$ & $\begin{array}{c}0.008^{\mathrm{a}} \pm \\
0.00\end{array}$ & $\begin{array}{c}0.011 \mathrm{a} \pm \\
0.00\end{array}$ & $\begin{array}{c}0.011 \mathrm{a} \pm \\
0.01\end{array}$ & $\begin{array}{c}0.008 \mathrm{a} \pm \\
0.00\end{array}$ & $\begin{array}{c}0.016^{\mathrm{a}} \\
\pm 0.00\end{array}$ & $\begin{array}{c}0.013^{\mathrm{a}} \pm \\
0.00\end{array}$ & $\begin{array}{c}0.013^{\mathrm{a}} \pm \\
0.01\end{array}$ & $\begin{array}{c}0.011^{\mathrm{a}} \pm \\
0.00\end{array}$ & $\begin{array}{c}0.013^{\mathrm{a}} \pm \\
0.01\end{array}$ \\
\hline \multirow[t]{2}{*}{$\mathrm{Fe} / 0.3$} & Water & $\begin{array}{c}0.044^{\mathrm{c}} \pm 0.0 \\
4 \\
\end{array}$ & $\begin{array}{c}0.036^{\mathrm{cd}} \pm \\
0.01\end{array}$ & $\begin{array}{c}0.098 \mathrm{a} \pm \\
0.01\end{array}$ & $\begin{array}{c}0.039^{\mathrm{cd}} \pm \\
0.01\end{array}$ & $\begin{array}{c}0.031 \mathrm{~d} \pm \\
0.00\end{array}$ & $\begin{array}{c}0.042^{\mathrm{c}} \\
\pm 0.00\end{array}$ & $\begin{array}{c}0.039 \mathrm{~cd} \\
\pm 0.00\end{array}$ & $\begin{array}{c}0.040^{\mathrm{c}} \pm \\
0.00\end{array}$ & $\begin{array}{c}0.063^{\mathrm{b}} \pm \\
0.01\end{array}$ & $\begin{array}{c}0.039 \mathrm{~cd} \pm \\
0.01\end{array}$ \\
\hline & Alkaline & $\begin{array}{c}0.044^{\mathrm{c}} \pm 0.0 \\
0 \\
\end{array}$ & $\begin{array}{c}0.033^{\mathrm{c}} \pm \\
0.00 \\
\end{array}$ & $\begin{array}{c}0.110^{\mathrm{a} \pm} \\
0.02 \\
\end{array}$ & $\begin{array}{c}0.035^{\mathrm{c}} \pm \\
0.01 \\
\end{array}$ & $\begin{array}{c}0.031^{\mathrm{c}} \pm \\
0.00\end{array}$ & $\begin{array}{c}0.040^{c} \\
\pm 0.01 \\
\end{array}$ & $\begin{array}{c}0.036 \mathrm{c} \pm \\
0.02 \\
\end{array}$ & $\begin{array}{c}0.038 \mathrm{c} \pm \\
0.01 \\
\end{array}$ & $\begin{array}{c}0.072^{\mathrm{b}} \pm \\
0.02\end{array}$ & $\begin{array}{c}0.038 \mathrm{c} \pm \\
0.01\end{array}$ \\
\hline \multirow[t]{2}{*}{$\mathrm{Ni} / 0.02$} & Water & $\begin{array}{c}0.090^{b} \pm 0.0 \\
0\end{array}$ & $\begin{array}{c}0.022^{\mathrm{de}} \pm \\
0.00\end{array}$ & $\begin{array}{c}0.040^{\text {cd }} \\
\pm 0.02 \\
\end{array}$ & $\begin{array}{c}0.140^{\mathrm{a} \pm} \\
0.03\end{array}$ & $\begin{array}{c}0.018 \mathrm{e} \pm \\
0.01\end{array}$ & $\begin{array}{c}0.090^{\mathrm{b}} \\
\pm 0.05\end{array}$ & $\begin{array}{l}0.090^{\mathrm{b}} \\
\pm 0.03 \\
\end{array}$ & $\begin{array}{c}0.090^{\mathrm{b}} \pm \\
0.00\end{array}$ & $\begin{array}{c}0.070^{\mathrm{bc}} \pm \\
0.02\end{array}$ & $\begin{array}{c}0.090^{\mathrm{b}} \pm \\
0.03\end{array}$ \\
\hline & Alkaline & $\begin{array}{c}0.090^{c} \pm 0.0 \\
0\end{array}$ & $\begin{array}{c}0.020^{\mathrm{f}} \pm 0 \\
.01\end{array}$ & $\begin{array}{c}0.034 \mathrm{de} \\
\pm 0.01\end{array}$ & $\begin{array}{c}0.320^{\mathrm{a} \pm} \\
0.01\end{array}$ & $\begin{array}{c}0.010^{\mathrm{f}} \pm 0 \\
.00\end{array}$ & $\begin{array}{c}0.080^{\mathrm{cd}} \\
\pm 0.03\end{array}$ & $\begin{array}{l}0.020^{\mathrm{cd}} \\
\mathrm{e} \pm 0.04\end{array}$ & $\begin{array}{c}0.060^{\mathrm{b}} \pm \\
0.01\end{array}$ & $\begin{array}{c}0.040 \text { def } \\
\pm 0.03\end{array}$ & $\begin{array}{c}0.060 \text { cde } \\
\pm 0.02\end{array}$ \\
\hline
\end{tabular}

Table 1: Metal Concentration of Boiled Water Extractions of Various Cooking Pots

Mean \pm SD with different letters in columns are significantly different (LSD test, $\mathrm{p}<0.05$ ). +Unboiled water served as control. MTL: (mg/ L) Maximum Tolerable Level (WHO, 2011) in drinking water.]

$\mathrm{CON}=$ Control, $\mathrm{NA}=$ New Aluminum pot, $\mathrm{CI}=$ Cast Iron pot, $\mathrm{OS}=$ Old stainless pot, $\mathrm{OA}=$ Old Aluminum pot, $\mathrm{TS}$ Titanium steel pot, $\mathrm{OE}=$ Old Enamel pot, $\mathrm{NS}=$ New stainless pot, $\mathrm{NE}=$ New Enamel pot.

Although there was a general trend of the concentrations of $\mathrm{Cu}, \mathrm{As}, \mathrm{Pd}$, and $\mathrm{Hg}$ being increased in boiled water compared to unboiled, but the values were statistically equal among the pots. There was a general decrease in Fe content of boiled water compared with the unboiled except for those boiled in Iron cat and clay pots.

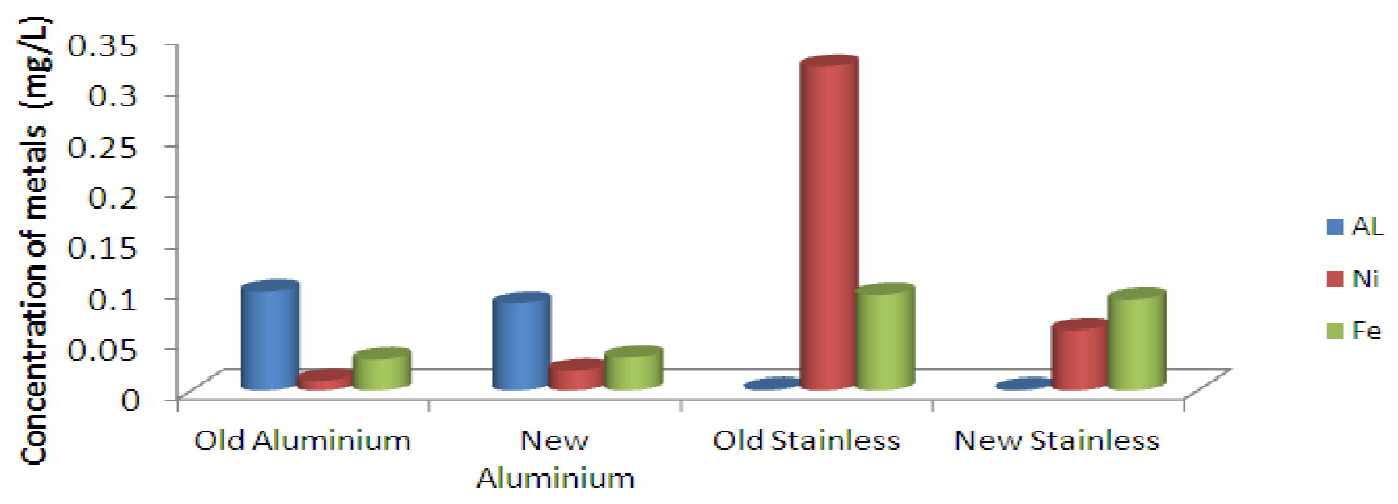

COOKING POTS

Figure 1: Concentration of Metals in the Old and New Versions of Cooking Pots

\subsection{Concentration of Metal in Boiled Alkaline Water}

The range of the metals in boiled alkaline water were as follows Aluminum (Al) $0.0042-0.098 \mathrm{mg} / \mathrm{L}$, Arsenic (As)

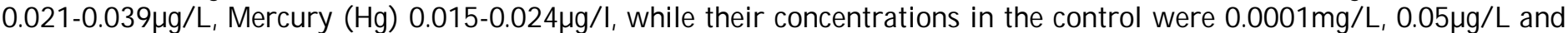
$0.030 \mu \mathrm{g} / \mathrm{L}$ respectively (Table 1$)$. The range of the other heavy metals were $0.07-1.11 \mu \mathrm{g} / \mathrm{L}, 0.008-0.016 \mathrm{mg} / \mathrm{L}, 0.031$ $0.110 \mathrm{mg} / \mathrm{L}$ and $0.01-0.32 \mu \mathrm{g} / \mathrm{L}$ for lead $(\mathrm{Pb})$, Cupper $(\mathrm{Cu})$, Iron $(\mathrm{Fe})$ and Nickel $(\mathrm{Ni})$ respectively, while their values were 
$1.16 \mu \mathrm{g} / \mathrm{L}, 0.018 \mathrm{mg} / \mathrm{L}, 0.044 \mathrm{mg} / \mathrm{L}$ and $0.09 \mu \mathrm{gL}$ in their control samples respectively. For Arsenal (As) the control sample recorded the highest concentration of $(0.050 \mathrm{\mu g} / \mathrm{L})$ while a decrease was observed for the different pots with the least As $(0.028 \mu \mathrm{g} / \mathrm{L})$ occurring in Aluminum cooking pots.

\subsection{Concentrations of Metals in Cooked Food Samples}

The concentrations of metals in cooked food samples were higher than their values in both boiled water and uncooked samples (TABLES 2-5). The cooking pots were observed to migrate higher quantities of metals during cooking of food compared to when they were used to boil water. Aluminum (Al) in the cooked and uncooked samples ranged from $0.042-$ $0.61 \mathrm{mg} / 100 \mathrm{~g}$, Ni ranged from $0.045-0.085 \mathrm{mg} / 100 \mathrm{~g}$, Fe ranged from $1.50-1.71 \mathrm{mg} / 100 \mathrm{~g}$, and Cu ranged from $0.65-$ $0.74 \mathrm{mg} / 100 \mathrm{~g}$ for the different foodstuffs cooked in different pots. The concentration of Ni was significantly $(\mathrm{P}<0.05)$ higher in old Stainless pot compared to other pots. On the average, foods cooked in old $\mathrm{Al}$ pot recorded the highest $\mathrm{Al}$ ion migration value of $0.62 \mathrm{mg} / 100 \mathrm{~g}$ though it jointly showed no significant variation $(\mathrm{p}<0.05)$ with the value for New Aluminum pot, $0.60 \mathrm{mg} / 100 \mathrm{~g}$. Fe concentration of the food cooked in some pot (e.g., Aluminum pot) decreased when compared to the uncooked sample. The least value for Fe was obtained for samples cooked in OA pot $(1.55 \mathrm{mg} / 100 \mathrm{~g})$. The result revealed no significant variation in Fe between the uncooked and food cooked with TS pot $(1.77 \mathrm{mg} / 100 \mathrm{~g})$ although the uncooked had significant variation with those cooked with other pots. Foods cooked with TS also showed statistical similarity with those cooked in SS $(1.67 \mathrm{mg} / 100 \mathrm{~g})$ and NA pots $(1.55 \mathrm{mg} / 100 \mathrm{~g})$. But those cooked with iron pot had higher iron contents of $2.058 \mathrm{mg} / 100 \mathrm{~g}$ (Table 3). Expectedly some of the pots maintained a pattern of metal leaching irrespective of the food they were used to cook while others were affected by food type. For example, boiling of tomato sauce for $6 \mathrm{~m}$ in an aluminum pot resulted in an increase of aluminum metal content of the tomato sauce from $0.001 \mathrm{mgAl} / 100 \mathrm{~g}$ to $0.099 \mathrm{mg} \mathrm{Al} / 100 \mathrm{~g}$. While for TS and SS pots the concentrations of Al increased from $0.00 \mathrm{mgAl} / 100 \mathrm{~g}$ to 0.001 and $0.041 \mathrm{mgAl} / 100 \mathrm{~g}$ respectively (Table2). Irrespective of the food cooked, old aluminum pot leached more aluminum ions than the new ones implying that pitting and scratching increase leaching of such pots (Hughes, (1992) 46-49. Since the pots used in this research did not migrate appreciable mercury, lead and arsenal in their water extracts, these three metals were not further investigated. In addition, there is very little research report on the leaching of mercury from cooking pot in a controlled environment such as $\mathrm{pH}$. That notwithstanding, Wook et al., (2013) stated that there was no resultant effect of heating on mercury content of foods.

\begin{tabular}{|c|c|c|c|c|c|c|}
\hline \multirow{2}{*}{ Cooking Pots } & \multicolumn{5}{|c|}{ Aluminum Ions (Mg/ 100g) Migrated into Cooked Food } \\
\cline { 2 - 7 } & Tomato & Beans & Yam & Rice & Meat & MEAN \\
\hline Control (raw) & 0.001 & 0.014 & 0.18 & 0.010 & 2.14 & 0.469 \\
\hline Titanium & 0.001 & 0.014 & 0.14 & 0.001 & 2.14 & 0.461 \\
\hline Enamel & 0.013 & 0.015 & 0.14 & 0.001 & 2.14 & 0.462 \\
\hline Stainless & 0.041 & 0.016 & 0.13 & 0.012 & 2.15 & 0.470 \\
\hline Cast Iron & 0.027 & 0.016 & 0.11 & 0.013 & 2.18 & 0.469 \\
\hline Clay & 0.027 & 0.031 & 0.69 & 0.043 & 2.51 & 0.660 \\
\hline New Aluminum & 0.083 & 0.350 & 0.77 & 0.048 & 2.54 & 0.758 \\
\hline Old Aluminum & 0.099 & $0.67 i$ & 0.97 & 0.075 & 2.55 & 0.873 \\
\hline
\end{tabular}

Table 2: Effect of Cooking Pot on Quantity of Aluminum Ions Migrated into Cooked Foods Allowable Dailly Intake (FAO/ WHO, 2011, EFSA, 2015) =0.14mg/ Kg Body Weight

\begin{tabular}{|c|c|c|c|c|c|c|}
\hline \multirow{2}{*}{ Cooking Pots } & \multicolumn{7}{|c|}{ Iron Ions (Mg/ 100g) Migrated Into Cooked Food } \\
\cline { 2 - 7 } & Tomato & Beans & Yam & Rice & Meat & Mean \\
\hline Control (raw) & 0.123 & 2.41 & 0.44 & 4.43 & 1.8 & 1.841 \\
\hline Titanium & 0.125 & 2.43 & 0.43 & 4.12 & 1.76 & 1.773 \\
\hline Enamelware & 0.133 & 2.44 & 0.42 & 3.87 & 1.78 & 1.729 \\
\hline Stainless & 0.138 & 2.42 & 0.42 & 3.62 & 1.74 & 1.668 \\
\hline Cast Iron & 0.211 & 2.85 & 0.48 & 4.65 & 2.18 & 2.074 \\
\hline Clay & 0.139 & 2.49 & 0.41 & 4.48 & 1.82 & 1.868 \\
\hline Aluminum & 0.112 & 2.32 & 0.35 & 3.56 & 1.63 & 1.594 \\
\hline Old Aluminum & 0.11 & 2.34 & 0.32 & 3.57 & 1.63 & 1.594 \\
\hline
\end{tabular}

Table 3: Effect of Cooking Pot on Quantity (Mg/ 100g) of Iron Migrated into Cooked Food $\mathrm{ADI}=18-30 \mathrm{mg} / \mathrm{Kg}(\mathrm{EFSA}, 2015)$ 


\begin{tabular}{|c|c|c|c|c|c|c|}
\hline \multirow{2}{*}{ Cooking Pots } & \multicolumn{7}{|c|}{ Nickel Ions (mg/ 100g) Leached into Cooked Food } \\
\cline { 2 - 7 } & Tomato & Beans & Yam & Rice & Meat & MEAN \\
\hline Control (raw) & 0.021 & 0.033 & 0.084 & 1.62 & 0.08 & 0.37 \\
\hline Titanium & 0.023 & 0.035 & 0.084 & 1.58 & 0.07 & 0.36 \\
\hline Enamelware & 0.025 & 0.040 & 0.084 & 1.56 & 0.11 & 0.36 \\
\hline Stainless & 0.065 & 0.125 & 0.125 & 1.98 & 0.18 & 0.495 \\
\hline Cast Iron & 0.028 & 0.017 & 0.085 & 1.52 & 0.12 & 0.35 \\
\hline Clay & 0.026 & 0.030 & 0.086 & 1.53 & 0.06 & 0.35 \\
\hline New Aluminum & 0.031 & 0.020 & 0.084 & 1.50 & 0.06 & 0.34 \\
\hline Old Aluminum & 0.032 & 0.020 & 0.084 & 1.50 & 0.06 & 0.34 \\
\hline
\end{tabular}

Table 4: Effect of Cooking Pot on Quantity of Nickel Migrated into Cooked Food Tolerable Daily Intake = 2.8 Micrograms per Kg Body Weight. \{EFSA, 2015\}

\begin{tabular}{|c|c|c|c|c|c|c|}
\hline \multirow{2}{*}{ Cooking Pots } & \multicolumn{7}{|c|}{ Copper Ions (mg/ 100g) Migrated into Cooked Food } \\
\cline { 2 - 7 } & Tomato & Beans & Yam & Rice & Meat & MEAN \\
\hline Control (raw) & 0.03 & 1.32 & 1.12 & 0.11 & 0.12 & 0.540 \\
\hline Titanium & 0.03 & 1.29 & 1.11 & 1.03 & 0.08 & 0.708 \\
\hline Enamelware & 0.03 & 1.29 & 1.11 & 1.03 & 0.06 & 0.704 \\
\hline Stainless & 0.03 & 1.26 & 1.06 & 0.9 & 0.06 & 0.662 \\
\hline Cast Iron & 0.04 & 1.24 & 1.06 & 1.01 & 0.06 & 0.682 \\
\hline Clay & 0.04 & 1.24 & 1.04 & 1 & 0.06 & 0.676 \\
\hline Aluminum & 0.04 & 1.22 & 1.04 & 1 & 0.04 & 0.668 \\
\hline Old Aluminum & 0.04 & 1.22 & 1.04 & 1 & 0.04 & 0.668 \\
\hline
\end{tabular}

Table 5: Effect of Cooking Pot on Quantity (Mg/ 100g) of Copper Migrated into Cooked Food PMTDI $=0.5 \mathrm{Mg} \mathrm{Kg}^{-1}$ Bodyweight FAO/ WHO, 2011, EFSA, 2015)

\subsection{Effect of Cooking Pot on Estimated Daily Metal Intake}

The estimated daily intake of metal ions to be ingested along with food cooked in the various cooking pots varied significantly and are as follows: $\mathrm{Al}$ in 0.119 to $0.224 \mathrm{~g} / \mathrm{g}, \mathrm{Fe}, 425$ to $0.456 \mathrm{~g} / \mathrm{g}, \mathrm{Ni}, 0.089$ to $0.127 \mathrm{~g} / \mathrm{g}$ while $\mathrm{Cu} 0.172$ to $01.182 \mathrm{~g} / \mathrm{g}$ (Table 6). The highest $(0.099 \mathrm{mg} / 100 \mathrm{~g}) \mathrm{Al}$ ion content of food occurred in the old Aluminum pot followed closely by that cooked in the new Aluminum pot (0.083) (Table 3). The least $(0.001 \mathrm{mg} / 100 \mathrm{~g})$ occurred in Titanium cooking pot. The EDI for occurred in Titanium pot.

\begin{tabular}{|c|c|c|c|c|}
\hline \multirow{2}{*}{ Cooking Pots } & \multicolumn{4}{|c|}{ Metal Ions (mg/ g) } \\
\cline { 2 - 5 } & $\mathrm{Al}$ & $\mathrm{Fe}$ & $\mathrm{Ni}$ & $\mathrm{CU}$ \\
\hline Control (raw) & $0.121^{\mathrm{a}}$ & $0.473^{\mathrm{a}}$ & $0.095^{\mathrm{a}}$ & $0.139^{\mathrm{a}}$ \\
\hline Titanium & $0.119^{\mathrm{a}}$ & $0.456^{\mathrm{a}}$ & $0.092^{\mathrm{a}}$ & $0.182^{\mathrm{b}}$ \\
\hline Enamelware & $0.119^{\mathrm{a}}$ & $0.444^{\mathrm{a}}$ & $0.094^{\mathrm{a}}$ & $0.181^{\mathrm{b}}$ \\
\hline Stainless & $0.121^{\mathrm{a}}$ & $0.429^{\mathrm{a}}$ & $0.127^{\mathrm{b}}$ & $0.170^{\mathrm{b}}$ \\
\hline Cast Iron & $0.121^{\mathrm{a}}$ & $0.529^{\mathrm{b}}$ & $0.091^{\mathrm{a}}$ & $0.175^{\mathrm{b}}$ \\
\hline Clay & $0.187^{\mathrm{b}}$ & $0.480^{\mathrm{a}}$ & $0.089^{\mathrm{a}}$ & $0.174^{\mathrm{b}}$ \\
\hline New Aluminum & $0.195^{\mathrm{c}}$ & $0.425^{\mathrm{a}}$ & $0.089^{\mathrm{a}}$ & $0.172^{\mathrm{b}}$ \\
\hline Old Aluminum & $0.224^{\mathrm{d}}$ & $0.427^{\mathrm{a}}$ & $0.089^{\mathrm{a}}$ & $0.172^{\mathrm{b}}$ \\
\hline PMDI per kg body weight & $0.14 \mathrm{mg}$ & $18-30$ & $2.8 \mathrm{ug}$ & $0.5 \mathrm{mg}$ \\
\hline
\end{tabular}

Table 6: Estimated Daily Quantity of Metal Ingested from Food Cooked in Various Pots

\section{Discussion}

\subsection{Leaching Capability of Various Cooking Pots When They Were Used to Boil Water (Simulated Cooking)}

'The high migration of $\mathrm{Al}$ ion from Aluminum cooking pots is in accordance with numerous studies done on the leaching capability of Aluminum cooking pot during food processing [Aujanue and Ellis, (2003); Zeo, (2005); Liang et al., (2010)]. Most Aluminum pots are purely forged from Aluminum metals, which are soft porous readily soluble metal at a high constant temperature (Greger, 1985, Liang et al., 2010). One recent report which investigated (at Cameroun) the possible contribution from Aluminum cooking pots to foods recooked at varying times (Bi 1992, Al-mayouf et al., 2008) revealed a high 
value of $\mathrm{Al}$ (30ppm-45ppm) for foods re-heated and stored in an old Aluminum cooking pots due to lack of refrigerators. Favorable reports supporting higher Al leachate from old Aluminum cooking pots compared to the new ones as observed in this work, abound (Inoue et al., (1988); Al-juhaiman, (2012); CMA, (2012). Aluminum pots leach more metals as they get older due to the abrasive cleaning methods usually adopted at homes. Abrasive washing of AL pots leads to pitting and increase in surface area of the cooking pot thereby allowing more metals to be impacted into to the food (Joshi et al, 2003). Comparing our results with that of the maximum permitted standard $(0.2 \mathrm{mg} / \mathrm{L})$ for Al in water by NIS (2007), we discovered that quantities we got were lower and within safe limits (FAO/ WHO (2011), Weidenhamer,et al 2014). Though values are within safe limits, lesser cooking in Aluminum pots should be encouraged so as to avoid bioaccumulation and its attendant effect in future (Odularu et al., 2013). Aluminum can bioaccumulate (JECFA,2010, FAO/ WHO,2015, EFSA,1990). Though enamel cooking pots are made from Aluminum, they are protected with coatings of inert materials, whose role is to prevent contamination of Aluminum coming from the cooking pot. This explains the low level of leachates observed in the enamel pot. In line with study by Zeo (2005), Aluminum detection in the clay cooking pot indicates the possibility of solubility and high concentration of the metal in the earth crust. This implies that the concentration of the metals will depend on the type of soil used in the clay pot production. Our assertion is in agreement with the work of Stahl et al. (2011).

Our data suggests that some quantity of $\mathrm{Ni} \mathrm{migrated} \mathrm{from} \mathrm{the} \mathrm{cooking} \mathrm{pot} \mathrm{into} \mathrm{the} \mathrm{water} \mathrm{during} \mathrm{boiling.} \mathrm{This} \mathrm{is}$ consistent with so many reports on the leaching from stainless steel pots into foods. Early studies have shown that old (used) stainless steel pots shed off Ni metals into foods [Thomas et al., (1974), Vrochte et al., (1991); Denkhaus et al., (2002); Kamerud et al., (2013); Nickelinstitute, (2015)]. The higher leaching of old stainless-steel pot compared to the new ones may be ascribed to the destruction of its protective coating during cleaning. The protective coating help prevent leachates from the cooking pot. Dabeka \& McKenzie, (1995) reported a significant increase in Ni concentration for water boiled in new stainless steel electric kettle. In their work concentrations of nickel increased from 100-400 $\mu \mathrm{g} / \mathrm{L}$ for water boiled in new stainless-steel kettles. The figures generated by Dabeka \& McKenzie (1995), differs from ours, but our result is in accordance with reports of no leachate from new stainless steel according to (Kurtus, 2012). Nickel serves no useful function in the body and therefore WHO, (2011) recommends identifying its contributing sources and efficiently limiting exposures. There are no known human enzymes or cofactors dependent on $\mathrm{Ni}$ for normal function (Kamerud et al., 2013). Toxicological studies indicate that a single oral dose of $\mathrm{Ni}$ as low as $67 \mu \mathrm{g}$ can cause Allergic Contact Dermatitis (ACD), eczema flare up, and even lead to systemic dermatitis in individuals sensitive to nickel (Denkhaus et al., (2002); Kamerud et al., 2013); Nickelinstitute, (2015)].

According to NIS (2007) Arsenal (AS) is present in water as arsenate or arsenite. It has been demonstrated to have no essential importance in the body. As is classified as a human carcinogen (Type A), and long-term drinking of arsenic contaminated water can cause skin, lung, bladder and kidney cancers [Agarwal et al., (1997); Hopenhayn, (2006); Hammond (2010)]. Previous research reports differ from our study on the loss of As during boiling [Jarup, (2003); (Muhammad et al., (2011); Parev et al., (2012). However, Jarup (2003) stated that heavy metals such as $\mathrm{Pb}, \mathrm{Cu}, \mathrm{As}, \mathrm{Hg}$, $\mathrm{Cr}$ and $\mathrm{Cd}$ are not destroyed by mere boiling of the water. In fact, the same amount of As value, $2.34 \mu \mathrm{g} / \mathrm{L}$ was observed when Parevet al., (2012) boiled contaminated water from three different locations in Argentina. So, the significant differences observed between the pots may be due to their different thermal diffusibility rate which led to the significant differences in the loss of water due to evapouration. Amongst the cooking pots Titanium steel (TS) pot had a better retention of As value of $0.044 \mu \mathrm{g} / \mathrm{L}$ which was followed by new Enamel pot and new Stainless pot respectively with quantities of $0.042 \mu \mathrm{g} / \mathrm{L}$ each, while the old Aluminum pot had $0.028 \mu \mathrm{g} / \mathrm{L}$. Since TS has a lower thermal diffusibility (Schrrle, 2006).), it can retain more nutrients than other pots with higher thermal diffusibility value ((). Interestingly the migration value of AS obtained in this work is below the provisional guideline value recommended by the FAO/ WHO (2011) for As in drinking water, Table 1.

The concentration of $\mathrm{Hg}$ metal $(0.030 \mu \mathrm{g} / \mathrm{L})$ in our control sample is in accordance with findings by Oniye et al., (2002) in their work of microbial and trace metal components in Table water sold in Enugu metropolis. Concentrations of $\mathrm{Hg}$ recorded in our study were below the maximum permitted limits $(0.001 \mu \mathrm{g} / \mathrm{L})$ according to NIS (2007). It can therefore be inferred that the cooking pots analysed had no form of mercury in them. Similarly, our data for $\mathrm{Pb}$ are lower than the safe limits recommended by NIS (2007) for drinking water $(0.01 \mathrm{mg} / \mathrm{L}$, probably due to the process given to the water to get it rid of lead [Kifle, (1985); Shumbulo et al., (1990); Tilahum and Ibrahim, (2001); Shelton et al., (2003); (Lamm and Kruse, 2005). Zarel et al., (2007); Kayode et al., (2010)]. The non-increase in copper leachates amongst the pots concurs with literatures such as that by Oscika et al., (2012) where they stated that due to the demerits associated with cupper's use as a cooking pot, cook ware manufacturers has stopped its use as a metal for forging cooking pots. Copper $(\mathrm{Cu})$ is a transition element which means it has oxidation states, $2+$ and 3+ usually. Ingesting large amounts of $\mathrm{Cu}$ can cause death by kidney failure in extreme cases [Olajire et al., (2003); Serife et al., (2010)]. The high concentration of iron in water boiled in Cast Iron (CI) and clay pots compared with other pots revealed that some quantity of Fe might have leached from these cooking pots into the water during boiling. Previous researcher had confirmed this inference, when they stated that processing of foods in cast iron pots is notable for increasing the mean concentration of Fe in food (Macrae et al., (1993); Cook et al., (1997)). Early Studies have shown Fe metal to be readily available in the earth crust (Shelton, 2003). However, iron from cooking pot comes in ferric form which the human body cannot assimilate (Carncross et al., (2005); Hiddendangers, (2015)]. Nevertheless, the study is in agreement with findings by Accominotti et al., (1998) who reported that the amount of metals released into food during cooking or processing were still less than the tolerable daily intake (TDI) recommended by FAO/ WHO (2011) 


\subsection{Leaching Capability of Various Cooking Pots When They Were Used to Boil Alkaline Water (Simulated Cooking)}

Sodium bicarbonate $\left(\mathrm{Na}_{2} \mathrm{HCO}_{3}\right)$ also known as baking soda is a pure substance which is alkaline in nature due to the formation of carbonic acid and hydroxide ions (Kurtuz, 2012). Generally boiled extractions of alkaline water had higher concentrations of most of the metals due to the high alkaline solution of the water. Weidenhamer, et al (2014) made a similar observation in their work with Aluminum pots. The high level of metal concentration in the boiled water especially in the old Aluminum and stainless pots when $\mathrm{Na}_{2} \mathrm{CO} 3$ was introduced to water prior to boiling was expected. The high alkaline water might have caused greater leaching of the metal into the water during boiling. The result is in accordance with numerous studies which report that a highly acidic or alkaline food increases the leaching potential of aluminum from Aluminum pot than their neutral counter parts (Garrison, 2008, Aujanue and Ellis, (2003); Liang et al., (2010); Kurtus, (2012, Weidenhamer, et al., (2014). In an alkaline solution, Aluminum reacts and becomes readily soluble in water thereby forming aluminates in the process (Garrison, 2008). Aluminum forms an oxide coating very quickly that protects it to a large extent, but in a salty environment it corrodes readily (

The most common form of corrosion (decomposition of metal surface) on Aluminum is pitting which occurs if Aluminum is in a humid environment and in the presence of salts. Compared to a number of other metals, Aluminum has good corrosion resistance because of its ability to form a layer of oxide (Al2O3) which provides protection against corrosion Fimreite, et al., 1997). However, the oxide layer is stable in the $\mathrm{pH}$ range of 4 to 9. If Aluminum is exposed to very acidic or very alkaline environments outside this $\mathrm{pH}$ range rapid metal corrosion may occur (Fimreite, et al., 1997). The thin natural film of Aluminum Oxide on the surface protects the bulk of the metal from further corrosion / oxidation. So, under normal conditions Aluminum does not corrode. But if Aluminum is put in an alkaline solution such as Sodium Hydroxide, the protective Oxide film is removed and the main bulk of the Aluminum will then corrode and dissolve very rapidly.

The migration values of lead from the pots to the solvents were not as higher as those reported by Weidenhamer, et al., (2014) where 29 Aluminum cooking pots commonly used in Cameroun both old and new were heated for $2 \mathrm{hrs}$ in the presence of an alkaline. The level of lead migrated from the pots (1.01-1.18ug/ L) were statistically the same and very much lower than the report of Weidenhamer, et al., (2014) whose report on lead levels ranged from 150ppm for the unboiled food to 700ppm for the boiled foods in the Aluminum pots. From the study, Weidenhamer et al., (2014) highlighted the dangers of Aluminum cooking pots as a potential source of lead contamination which must be avoided. Even in small amounts, lead is extremely toxic and can cause brain or nerve damage and impair the immune system (Rebaniak et al 2014). Weidenhamer et al., (2014) claimed that lead is actually not used in cooking pot forging, but other components used may resulted in the increase in lead values of Aluminum cooking pots (Shelton et al., 2003). The discrepancy in this study may be due to the methodology adopted to assess this trace metal since there are no standards for measurement of leachates from cooking pots. The insignificant increase in the level of lead in boiled alkaline water noticed in this work may be due to loss of water through evapouration because of the presence of the sodium bicarbonate which acted as an impurity to reduce water boiling time thereby attaining evapouration faster (Chibuike et al., 2015). It may also be linked to the thermal diffusibility of material used to forge each cooking pot. Material with low thermal diffusibility, retains more nutrients than that with a higher heat diffusibility (Hirata, Y., 2009; Ross, 2015).

Our results on copper metal migration differed from that reported by Araya et al., (2003) where copper concentrations in drinking-water increased during boiling in systems with an acid $\mathrm{pH}$ or carbonate waters with an alkaline $\mathrm{pH}$. The apparent reasons for the discrepancy maybe attributed to factors such as non-uniform experimental designs and choice of method for copper analysis (Rajwanshi et al., 1997). In terms of iron migrations, our findings are in consistent with statement by Kurtuz, (2012) that the cooking surface of cast iron pot in an acidic or alkaline medium increases the leaching of iron into food cooked with it. Macrae et al., (1993) had earlier reported that processing of foods in cast iron pot contributes to the increase in concentration of Fe naturally present in foods. Chibuike et al., (2015) on their report asserted that the presence of impurities such as sodium bicarbonate increases the rate at which water boils by helping to break down the hydrogen bonding of water molecules which fastens the boiling time and increases evapouration. This could offer explanation for the observed higher $\mathrm{Ni}$ leachates and other metals in alkaline environment as declared in this research. Our observation also tallies with that of Kurtus (2012) who stated that due to the removal of the protective layer as well as aging of the pot, old stainless steel leached more $\mathrm{Ni}$ than the new one, and that alkaline medium increases the mobility of nickel in stainless steel and may increase nickel concentration in foods processed in them. Kamerud, et al, (2013) had a different report. They stated that nickel and chromium migration occurred more in new stainless pot than in the old version. On his own side, Kurtus (2012) disagreed with the use of baking soda as a method to determining metal leaching from cooking pots in a stimulated cooking procedure. He argued that most foods are not as highly alkaline as baking soda, and seldom if ever would one cook with a baking soda, so it is not a true representation of the leaching of metals from cooking pot. However, information generated from solvent extracts of the various cooking pot provided an insight as per their leaching capabilities.

\subsection{Migration of Metal from Cooking Pot during Cooking of Food}

The higher concentrations of metals in cooked food samples compared with the raw samples confirm that there is migration of metals from the cooking pots into the food. This is in agreement with the report by Dabonne et al., (2010) who noted that, the level of Aluminum increased from $1.60 \mathrm{mg} / \mathrm{kg}$ in uncooked rice to $18.1 \mathrm{mg} / \mathrm{kg}$ in rice cooked with traditional cooking pot made of Aluminum. Our observation is also in agreement with researchers who claimed that cooking food in $\mathrm{Al}$ pot increases its content in foodstuffs not less than $1 \mathrm{mg} / \mathrm{kg}$ for about half the foodstuffs examined, and less than $10 \mathrm{mg} / \mathrm{kg}$ for 
$85 \%$ of the foodstuffs examined (Pennington and Jones, 1989). The range of Al ion recorded in cooked and uncooked food of our samples were higher than the recent safe limits for food $(1.00 \mathrm{mg} / \mathrm{kg})$ as stated by JECFA (2010), Stahl et al 2017a-c). Studies have also shown that, worn out or pitted inferior pot most frequently take up more $\mathrm{Al}$ from its containers [Hughes, (1992); Greger et al., (1985)]. Earlier reports had suggested that, the longer the cooking time, the greater the accumulation of aluminum in the food through leaching from the Aluminum pot during food processing (Weidenhamer et al., (2014)). Our report concurs with the opinion (Stahl et al. 2011, Stahl et al 2017-a)) that cooking food with Aluminum pot may be one of the major avenues of ingesting $\mathrm{Al}$ into human bodies. Increased Aluminum exposure can be compensated for by excretion via faeces and urine (for healthy kidneys) but Kidney insufficiency was shown to result in increased Aluminum concentrations in the kidneys of dialysis patients, (Stahl et al. 2017a-b).

The reports of statistical $(p<0.05)$ differences between the pots in their interaction cum migration of metals into food during cooking are in agreement with some previous works which demonstrated that increased concentrations of complexing ions (organic acid, fluoride ions, or $\mathrm{OH}$, etc) significantly enhance the release of aluminum (Gbolade et al (2003);; Stahl et al. (2011); Chibuike et al., (2015) into the food being cooked, and that aluminum leaches most easily from worn or pitted inferior pots and pans (Hughes., (1992), Rojoma, et al (2010). Greger, et al (1985) added that the amounts of aluminum that accumulate in foods during preparation also depend on the length of cooking periods, intensity of heat and the types of utensils. They reported that tomatoes heated in aluminum pans for $6 \mathrm{~m}$ accumulated only $0.02-0.03 \mathrm{mg} \mathrm{Al} / 100 \mathrm{~g}$, while tomato cooked for $3 \mathrm{~h}$ in aluminum pans accumulated $5.7 \mathrm{mg} \mathrm{Al} / 100 \mathrm{~g}$. Therefore, we infer that long periods of cooking in aluminum pots should be discouraged and leftover foods should not be kept in aluminum pans. This is to avoid excess aluminum ion intake and the resultant health effects on organs of the body. A school of thought believes that Aluminum pans do not pose a health risk to their users, even if they are scratched or pitted and that the amount of aluminum that leaks into food is negligible, and far less than that consumed through other methods. Our take on this is that exposure to aluminum is hazardous if not today then tomorrow since it can bioaccumulate in the body (Greger 1985, Semwal et al, (2006). This is true because the effects of exposure to any hazardous substance including aluminum depend on the dose, the duration, how one is exposed, personal traits and habits, and whether other chemicals are present or not (WHO 2001, FAO 2011). The fact is that aluminum can build up in the body when the body detoxification mechanism is weak/ overworked. So, ingestion of Al ion should be discouraged since $\mathrm{Al}$ has no known benefit to the human body despite its abundance in nature. Furthermore, recent studies on animal by FAO/ WHO Expert Committee on Food Additives (JECFA, 2008, 2010) and the Scientific Committee for Food (SCF) and European Food Safety Authority (EFSA, 2015) has moved the TWI for AL ion from $7 \mathrm{mg}$ to $1.0 \mathrm{mg} / \mathrm{kg}$ body weight following the reported toxicity of $\mathrm{Al}$ ion to animals at lower dosages than $7.0 \mathrm{mg} / \mathrm{kg}$ per week. This adjustment synchronized the combined findings of various studies and the fact that there is an accumulation of aluminum in the body. This represents the present criterion recognized by the European Union [EU 2015/ 2016]. Accordingly, an adult weighing $70 \mathrm{~kg}$ can consume $70.0 \mathrm{mg}$ aluminum per week for a lifelong period, and $15.0 \mathrm{mg}$ for a child weighing $15 \mathrm{~kg}$ (Stahl et al.2011). Minimal exposure of aluminum to our bodies may not be a problem as human bodies can excrete small amounts very efficiently [52]. But unfortunately, due to many reasons like we said earlier, most of us get exposed to and ingest more than what our bodies can handle (EFSA, 2015). Please note that the recommended levels are for healthy persons with good renal functions. In cases where the renal system is not efficient the aluminum migrated into cooked food (no matter how little) will represent a health risk. Some researchers are still maintaining that aluminum present in food utensils can expose humans to the ingestion of big quantities of aluminum [Stahl et al.2011; Al Juhaiman, (2012). Odularu, et al, (2013). Stahl et al.2017a-c], especially in acidic dishes.

The loss in Fe content in food cooked with TS, SS and AL pots may be as a result of Fe lost to the cooking water which was discarded. This report is similar to findings by Eka (1985) where boiling of yam and cocoyam resulted in the removal of considerable amount of minerals due to leaching into the cooking water. The result also implies that none of the three cooking pots mentioned above are not forged from Fe steel. This observation differs from that done by Dan and Ebong (2013) where they reported a higher value of iron for foods cooked with stainless steel stating that stainless steel is a metal alloy which contains more than fifty percent (50\%) Fe be it ferritics or martenistics. The observations of this research tallies with Cheng and Brittin (1991) who confirmed other previous research that foods cooked in iron utensils were greater in iron content than foods cooked in non-iron utensils. Hence using cast iron pots to cook can expose individuals to high intake of iron metal. Since many people have iron deficiencies due to inadequate intake of iron, one might suggest that all cooking utensils be iron. But that is not the end of the story. The reality is that ions from cast iron cooking pot is in ferric form $\left(\mathrm{Fe}^{3}+\right)$, a transition element (hydrated form) which undergo progressive hydrolysis to yield insoluble ferric hydroxide $\left(\mathrm{Fe}(\mathrm{OH})_{3}\right.$ ' Actually iron exists in two forms: ferrous $\mathrm{Fe}^{2}+$ and ferric-Fe $\mathrm{Fe}^{3}+$. Ferrous form is more soluble in water at physiological $\mathrm{pH}$. Ferrous iron is what makes blood red and comes from foods. Iron is used by the metabolic reaction only when it is in reduced form (ferrous state $\mathrm{Fe}^{2+}$ ) but it is stored and transported in the body as ferric ion $\left(\mathrm{Fe}^{3+}\right)$. The body cannot assimilate properly the ferric from of iron (from a cast iron pan) so the ingested ferric iron gets treated by the body as a heavy metal and ends up getting stuck in the liver and kidneys Ekalobi, (2008). It should be noted that ferric form of iron is stored in the body, so it can accumulate over time, contributing to joint pain/ arthritis, digestive troubles, depression, impotence, early menopause, and other issues associated with iron toxicity (Yaquat.et al, (2000), Cheng, and Brittin, (1991). Since cast iron is a toxic inassimilable kind of iron, it then means that a cooking pot that leaches a large amount of $\mathrm{Fe}^{3+}$ constitutes health danger and not healthy as some people believe. Urinary and faecal iron excretion is very low, thus, apparent iron absorption will practically equal apparent iron retention (Wienk et al, 1999) 
The observed decrease in Ni value for food cooked in the various pots with the exception of stainless steel pots is inline with expectations since the other pots do not have Ni in their structural make-up. The high Ni content food cooked in SS pot may be attributed to the leaching of the metal from stainless steel pot into the food samples. This is consistent with the findings by other researchers that, some quantity of $\mathrm{Ni}$ is always transferred into foodstuffs cooked with stainless steel utensils (Agarwal et al., (1997); Kumar et al., (1994). Furthermore, the obtained results from this study is consistent with the report by NIDI (1994) that, the release of nickel ions from stainless steel cooking pots into foodstuffs is generally less than 0.1 $\mathrm{mg} / \mathrm{kg}$. The range for $\mathrm{Ni}$ obtained in this study is lower than $0.15-0.70 \mathrm{mg} /$ day recommended by Codex (1995) as the daily intake of nickel via foodstuff. However, when it comes to nickel the focus is not on permissible levels but rather on sensitivity since nickel can cause allergic reactions in sensitive individuals (Veien, (1989); Veien and Menné, (1990). Toxicological studies indicate that a single oral dose of $\mathrm{Ni}$ as low as $67 \mu \mathrm{g}$ can cause Allergic Contact Dermatitis (ACD), eczema flare up, and even lead to systemic dermatitis in individuals sensitive to nickel [Kamerud, et al (2013), NickelInstitute, (2015). Our findings differs from the report of (Stahl et al., (2011), Kamerud, et al (2013), who observed as high as 88ug/ $126 \mathrm{~g}$ of nickel in cooked food. And nickel in stainless steel is a toxic heavy metal that has well-studied negative effects on the female reproductive organs. According to some workers (Hiddendangers (2015) abrasive washing of stainless steel can cause small amounts of chromium and nickel to be released into food.

According to Codex (1995) copper is naturally present in most foodstuffs in the form of copper ions or copper salts. $\mathrm{Cu}$ though needed in the body can be harmful if present in excess amount as it acts as a hemolytic agent (Aaseth and Norseth, 1986). The $\mathrm{Cu}$ values of cooked foods were significantly different $(\mathrm{P}<0.05)$ from the uncooked foods among the pots. The uncooked had the higher copper values than the uncooked. The above result differs from findings by Dan and Ebong (2013), for stable foods where $\mathrm{Cu}$ values increased from the uncooked foods $1.59 \mathrm{mg} / \mathrm{kg}$ to $2.43 \mathrm{mg} / \mathrm{kg}$ in the Aluminum pots after cooking. He further stated that Aluminum cook wares may contain alloying elements such as Magnesium, silicone, iron, manganese, copper and zinc. On comparing the results obtained for cupper with the Provisionally Maximum Tolerable Daily Intake (PMTDI) for $\mathrm{Cu}$ metal as stated by JECFA (1989), it was observed that Cu concentration in this study for the different cookware samples and the uncooked sample, were not higher than standard required by the body.

\section{Conclusion}

Metals can migrate from cooking pots into food during cooking depending on materials used to forge the pot but the intensity of the migration depends on the food being cooked. Porousity of pot surfaces (as affected by usage of the pot (especially aluminum and stainless) influences the leaching capabilities of cooking pots. Older pots with pitting surfaces leache more metals than their new versions probably because new pots have nonporous surfaces therefore should be avoided. We confirmed that titanium steel and enamel coated pots leached insignificant traces of metals in all cases of cooking compared to the other pots tested. The data from this study has evidence that aluminum, nickel and iron do migrate from cooking pot into food at levels above the permissible standards depending on the type of food and pot used for the cooking. Our work has demonstrated that the problem of metal leaching is more or less arising from the pot; though food type affected the concentrations of metals leached by each pot. We suggest dietary exposure of metals be avoided because metal (e.g. aluminum) exposure does have any known positive impact on human's health even if does not cause any verified illness.

\section{Funding}

This research did not receive any specific grant from funding agencies in the public, commercial, or not-for-profit sectors.

\section{References}

i. Aaseth, J., and Norseth, T., (1986). Copper. In: Handbook On The Toxicology Of Metals. $2^{\text {nd }}$ edn. Elsevier Publishers, Amsterdam, Pg.70-71.

ii. Accominotti, M., Bost, M., Haudrechy, P., Mantout, B., Cunat, P. J., Comet, F., Mouterde, C., Plantard, F., Chambon, P., and Vallon, J.J., (1998). Contribution to chromium and nickel enrichment during cooking of foods in stainless steel utensils. Contact Dermatitis. 38 (6): 305-310

iii. Agarwal P Srivastava S.Srivastava M.M. .Prakash S.RamanamurthyRM.ShrivastavS.Dass, (1997) Studies on leaching of $\mathrm{Cr}$ and $\mathrm{Ni}$ from stainless steel utensils in certain acids and in some Indian drinks. Science of The Total Environment Volume 199, Issue 3, 1 July 1997, Pages 271-275 https:/ / doi.org/ 10.1016/ S0048-9697(97)05455-7,

iv. Al Juhaiman L. A., (2012). Estimating aluminum leaching from aluminum cookware in different vegetable extracts. International Journal of Electrochemical Science. 7: 7283-7294.

v. Alice M, Olivier M, Walter M, Eugenia B , Fernand B , Ahmed B , Florian V , and Candice S Impact of Boiling Conditions on the Molecular and Sensory Profile of a Vegetable Broth* J. Agric. Food Chem., 2015, 63 (5), pp 1393-1400

vi. Al-Mayouf A., Al Juhaiman L., Al-Suhybani A., (2008). Corrosion of Aluminum in ascorbic, citric and tartaric acids with/ without chloride ions. Anti-Corrosion Methods and Materials. 55(2): 79-83

vii. AOAC (1990) Official methods of analysis of the Association of Official Agricultural Chemists, 15th edn. AOAC, Washington

viii. Araya, M., Henry, P.K., and Collins, W.L., (2003). Gastrointestinal symptoms and blood indicators of copper load in apparently healthy adults undergoing controlled copper exposure. Amer. J. of Clinical Nutr. 77: 646-650Audrey V.I, 
Woodgate B.P., Koutrey E.J., and Steven S.C., 2006. Studies on leaching properties of metals from cook ceramics. British J. Pharmacology and Toxicology. 2(4), pp. 90-95.

ix. Aujanue, I.F and Ellis, D.E., (2003). Solubility control on Aluminum in drinking water at relatively low and high $\mathrm{pH}$. General Chemistry. 36 (17): 4356-4368.

x. Bassioni, G. et al. (2012) 'Risk Assessment of Using Aluminum Foil in Food Preparation', Int. J. Electrochem. Sci, 7, pp. 4498-4509.

xi. Baht, Ramesh V \& Moy, Gerald G. (1997) .Monitoring and assessment of dietary exposure to chemical contaminants / Ramesh V. Baht \& Gerald G. Moy. http:/ / www.who.int/ iris/ handle/ 10665/ 54793

xii. Bhat, R., Kiran, K., Arun, A.B. Karim, A. (2010) Determination of Mineral Composition and Heavy Metal Content of Some Nutraceutically Valued Plant Products. Food Anal. Methods 3 (3) 181 - 187https:// doi.org/ 10.1007/s12161009-9107-y

xiii. Bi 1992 cited in Ghada B, Fathia SM, Essam A and Issam K. 2012, Risk assessment of using Aluminum foil in Food preparation. Inter J. Electrochemical.Sci. 7 4498-4409

xiv. Carncross G., Minareci, E., Ozoen, G., (2005). Determination of heavy metals in fish, water and sediments of avsar Dam lake in Turkey. Iran J. Enviro. Health. 6(2): 73-80.

xv. Chibuike, N.C., Ibeawuchi D.I., Chinedu, A.M., (2015). General understanding of the principles and modern applications of thermodynamics. RCB publishers. Lagos. Pg: 344-347.

xvi. Cheng, Y.J. and Brittin, H. C 1991: Iron in food: effect of continued use of iron cookware. J. of food Sci 56(2): 584-585.

xvii. Codex Alimentarius Commission (CAC). Codex general standard for contaminants and toxins in foods; Joint FAO/ WHO food standards programme. 1995; Doc. no. CX/ FAC 96/ 17.

xviii. Cook J.D., Reddy M.B., Hurrel R.F., Juillerat M.A., and Buri J., (1997). The influence of different cereal grains on iron absorption from infant cereal foods. America J. Clin. Nutr. 65: 964-969

xix. Cookware Manufacturers Association (CMA), (2012). Technical engineering standards for cook-ware and bakeware. Mountain Brook: AL:CMA;.

xx. Dabeka, R.W., and McKenzie, A.D., (1995). Survey of lead, cadmium, fluoride, nickel, and cobalt in food composites and estimation of dietary intakes of these elements by Canadians in 1986-1988. J. of the Association of Official Analytical Chemists International. 78: 897-909

xxi. Dabonne S., Koffi B., kouadio E., Due E., and Kouame L., (2010). Traditional utensils: Potential source of poisoning by heavy metals. British Journal of pharmacology and to Toxicology, 1(2):90-92.

xxii. Dan, E. U., and Ebong A.G., 2013. Impact Of Cooking Utensils On Trace Metal Levels Of Processed Food Items. Msc Disertation, University Of Uyo. Nigeria. Pp 44-54.

xxiii. Denkhaus, E., Salnikow, K., Capwer, M.N., (2002). Nickel essentiality, toxicity, and carcinogenicity. Crit. Rev. Oncol./ Hematol. 42: 35-56.

xxiv. Eka, O. U. (1985). The chemical composition of yam tubers. In: Advances in yam research. G. Osuji (ed.). Enugu, Nigeria: Anambra State University Press. pp. 51-74.

xxv. Ekalobi, C.I., 2008. A physiological based model for the ingestion of trace metals by humans. Toxicol. Appl. Pharmacol. 118: $16-29$.

xxvi. EU Commission Regulation Amending Regulation (EC) 2015/2016; No 1881/2006 as regards maximum levels of inorganic arsenic in foodstuffs. http:// eur-lex.europa.eu/legalcontent/ EN/TXT/ PDF/ ?uri=CELEX:32015R1006\&from=EN

xxvii. European Food Safety Authority (EFSA) : http:/ / www.efsa.europa.eu/ 2015 [accessed 5/ 1/ 2016]

xxviii. FAO, (2001). Food security: concept and measurements www.fao.org/ docrep/ 005/y4671e/y4671e06.htm [accessed $15 / 05 / 2015]$

xxix. FAO/ WHO Expert Committee on Food Additives Seventy-second meeting of the JECFA. Summary and Conclusions, Rome, 2010; 16-25 February, pp 16

xxx. FAO/ WHO Expert Committee on Food Additives. Evaluation of certain food additives and contaminants: Seventy-third report of the Joint FAO/ WHO Expert Committee on Food Additives. WHO Technical Report Series; 2011; No 960, pp 228

xxxi. FAO/ WHO Expert Committee on Food Additives Seventy-second meeting of the JECFA. Summary and Conclusions, Rome, 2010; 16-25 February, pp 16

xxxii. FAO/ WHO Expert Committee on Food Additives. Evaluation of certain food additives and contaminants: Seventy-third report of the Joint FAO/ WHO Expert Committee on Food Additives

xxxiii. Fimreite, N., Hansen, O.Ø. and Pettersen, H.C., 1997. Aluminum concentrations in selected foods prepared in aluminum cookware, and its implications for human health. Bulletin of environmental contamination and toxicology, 58(1), pp.17

xxxiv. Garrison, S.P., (2008). The environmental chemistry of Aluminum. Denver Publishers, London. Pp: 55-58.

xxxv. Gbogbo F, Arthur-Yartel A, Bondzie JA, Dorleku W-P, Dadzie S, Kwansa-Bentum B, et al. (2018) Risk of heavy metal ingestion from the consumption of two commercially valuable species of fish from the fresh and coastal waters of Ghana. PLoS ONE 13(3): e0194682. https:/ / doi.org/ 10.1371/ journal.pone.0194682 
xxxvi. Gbolade, W.K., Dashtag, G.A., and Hommels, R.E., 2003. Study of metal release from cookwares. Polish Journal Of Enviro. Studies. 15(2): 139-142.

xxxvii. Greger, J.L., Goetz, W., and Sullivan, D. 1985. Aluminum levels in foods cooked and stored in aluminum pans, trays and foil.J. Food Protect. 48 (9): 772-777.

xxxviii. Hiddendangers 2015. Hidden dangers in cook wares: stainless steel, cast iron, glass, teflon, Aluminum (Online). Avaliable at :http.// www .happycookingco.com/ hiddendanger.cfm [Accessed, 22, January 2014].

xxxix. Hirata, Y., 2009. Thermal conduction model of metal and ceramics. Ceramics International, 35(8), pp.3259-3268.

xl. Hopenhayn C., (2006). Arsenic in drinking water: Impact on human health. Elements. 2(2): 103-107 http:/ / www.nickelinstitute.org/ en/ KnowledgeBase/ TrainingModules/ Effective-Use-of-Nickel-in-Stainless-steel.aspx. [Accessed: 23rd June, 2015].

xli. Hughes J.T., 1992. Aluminum and your health. Cookware Update Bulletin, 24 May, 1992. Pg8.

xlii. Inoue T., Ishiwata H., Yoshihira K., (1988). Aluminum levels in food-simulating solvents and various

xliii. Jarup, L., (2003). Hazards Of Heavy Metal Contamination. Brt. Med. Bulletin, 68: 167-182.

xliv. JECFA (2008) FAO/ WHO Expert Committee on Food Additives Seventy-second meeting of the JECFA. Summary and Conclusions, Rome, 2010; 16-25 February, pp 16 WHOTechnical Report Series; 2011; No 960, pp 228

xlv. JECFA,(2010). Evaluation of certain food additives and contaminants. Thirty-third report of the Joint FAO/ WHO Expert Committee on Food Additives. World Health rganization,Technical Report Series 776. http:/ / www.inchem.org/ documents/ jecfa/ jecmono/v024je07.htm

xlvi. Joshi S.P., Toma R.B., Medora N., O'Connor K.,(2003). Detection of Aluminum in sauces packaged in Aluminum pouches. Food Chemistry, 83: 383-386

xlvii. Kamerud, K.L., Hobbie, K.A., and Anderson, K.A., 2013. Stainless steel leaches Nickel and Chrominum into foods during cooking.J. Agric. And Food Chem. 4: 1-7.

xlviii. Karbouj, R. Food Chem. Toxicol, 45(9) 2007 1688. in Mohammad F.S, AlZubaidy, EAH and Bassioni G. 2011. Effect of Aluminum leaching processes of cooking wares on Food. Inter J of Electrochemical.Sci. 6 222-230

xlix. Kayode, P.W., Turkey, G. B. and Effiong, N.G., (2010). Lead: occurrence, toxicity and separation techniques in water. Water Res. 6(3): 4304-4312

l. Kifle, H.P., (1985). Study on polluting properties of lead residue contaminated sites in plateau state, Nigeria. J. Enviro. Engr. 30(3): 915-918

li. Kurtus, R.T, 2012). Leaching from cooking surfaces (Online). http: www.school-for-champions.com/ health/ cookingsurfaces.htm. [Accessed: 26-April, 3013].

lii. Lamm, S. H., and Kruse, M.B., (2005). A review of the epidemiological literature on the role of environmental cupper exposure and cardiovascular diseases. Toxicology and Applied Pharmacology. 223 (8): 312-326

liii. Liang T.J., Stag, R.W., and Shuttle-Wort R.M., (2010). The Effect Of Aluminum An Ionic Regulation. Enviroment Toxicololgy water quality. 9(21): 115-121

liv. Macrae, R., Robison, R.K. and sadler, M. J., (1993). The Encyclopedia Of Food Science: Food technology and nutrition. Academic press, New York. Pp: 552-565

lv. Mohammad F.S, AlZubaidy, EAH and Bassioni G. (2011). Effect of Aluminum leaching processes of cooking wares on Food. Inter J of Electrochemical.Sci. 6 222-230

lvi. National Residue Survey (NRS) NRS Annual Report 2010-11. Australian Government. Department of Agriculture, Fisheries and Forestry, Canberra. 2012; 272.

lvii. NickelInstitute, 2015. The Effective Use of Nickel in Stainless Steels (Online). Avaliablefrom:

lviii. NIDI, (1994). Status report. Nickel Development Institute. SR-0003.

lix. Nigeria Industrial Standards (NIS), (2007). Nigeria standard for drinking water quality. Standards Organization of Nigeria. Pg: 1 -30.

lx. Odularu, A.T., Ajibade, P.A., and Onianwa, P.C., 2013. Comparative study of leaching of aluminum from Aluminum, clay, stainless steel and steel cooking pots. ISRN Public Health. 20 (1): 1-4.

lxi. Olajire, A. A, Ayodele, E.T., Onyedirdan, G.O., Olugbemi, E.A. (2003). Levels and specification of heavy metals in soils of industrial southern Nigeria. Enviromental monitoring Assesment. 85(2): 135-155

lxii. Oniye, T.U, Akudinobi C.B., Halim, R.K, Loeb, L.A., (2002). Microbial and Trace metal component in bottle water sold in Enugu state. Published Bsc research work. Enugu state University Enugu State. Pg: 42-60.

lxiii. Oscika, E.F., Laswai, H.S, Atangana A.R., chagomoka. T.G, Ndango, R.G. (2012). Oxidative effect of Nutrients and antinutrients composition of raw, cooked and sun. dried sweet potato leaves on copper wares. Afr. J. Food Agric. Nutr. Dev. 11(5).42-54.

lxiv. Osunde, D.A., Etika B.O., Ndem, S.I., and Kalu C.N., (2003). Leaching Metals And Chemicals From Cooking Surfaces. Stimac Prints, Lagos, Nigeria. Pp: 24-66.

lxv. Parev, T.L., Litter, M.J., Nath, J.M., (2012). One Century Of Arsenic Exposure In Latin America: A Review Of History And Occurrence From 14countries. Med. Ame. Res. 33: 44-48.

lxvi. Pennington, J. A., Jones, J. W., (1989). Dietary intake of Aluminum. Aluminum and Health- A Critical Review. Gitelma books, Paris. Pp. 67-70. 
lxvii. Ranau R, Oehlenschläger J, Steinhart H: Aluminum levels of fish fillets baked and grilled in Aluminum foil. Food Chem 2001, 73:1-6

lxviii. Rajwanshi P., Singh V., Gupta M. K., and Dass S., (1997). Leaching of Aluminum from cookwares: A review, Environmental Geochemistry and Health. 19(1): 1-18.

lxix. Rebeniak M, Wojciechowska-Mazurek M, Mania M, Szynal T, Strzelecka A, Starska K. (2014). Exposure to lead and cadmium released from ceramics and glassware intended to come into contact with food. US National Library of Medicine Rocz Panstw Zakl Hig. 2014;65(4):301-9.

lxx. Rojoma V.D., Dan J.C., Dakuji N.F. and Nsuja G.H., 2010. Estimation of the bioavaliabiity of trace metals from cooking utensils in processed food items. Annals food science and technology. 14(2):350-356.

lxxi. Ross, A., 2015. Trace metal dissolved from kitchen utensils. Envir. Contamination And Toxicology. 52(4): $342-355$.

lxxii. Schrrle, U.K., (2006). Salad master 316 TI stainless steel Taninum cookware(online). Available at http:/ / www.happycooking co.com/316-ti-titanium-stainless-steel-cookware.cfm. (Accessed: 4 August, 2014).

lxxiii. Semwal, A., Padmashree, M. A., Khan, G. K., Sharma, G.F., and Bawa, A. S., (2006). Leaching of Aluminum from utensils during cooking of food. Journal of the Science of Food and Agriculture. 86 (14): 2425-2430.

lxxiv. Serife, R.B., Boluwaju, C.B., Ajayi, I. I., (2010). Risk assessment of cupper in paddy soil and rice sample collected from an industrial park in Ogun state.J. Human Agric. 12(2): 92-95

lxxv. Sharieff, W., Dofonsou, J. and Zlotkin, S., 2008. Is cooking food in iron pots an appropriate solution for the control of anaemia in developing countries? A randomised clinical trial in Benin. Public health nutrition, 11(9), pp.971-977.

lxxvi. Shelton R., Stanford, G., and Finghley, J., 2003. Aluminum Toxicity: The hidden danger of cookwares (online). http/ / conscious cooks .com/ hidden-dangers. [Accessed 4th July, 2014].

lxxvii. Shumbula, T.Y., Jin, Y.L., Yu, S.H., Zhu, C.K. (1990). Trace metal contamination of urban soils in china. Sci. Res. Environ. 17(6): 17-23.

lxxviii. Smart G. A. \& J. C. Sherlock Nickel in foods and the diet. Pages 61-71 | Published online: 10 Jan 2009. https:/ / doi.org/ 10.1080/ 02652038709373616

lxxix. Soni et al , 2001 Reg Toxicol Pharma, 33: 66. cited in Mohammad F.S, AlZubaidy, EAH and Bassioni G. 2011. Effect of Aluminum leaching processes of cooking wares on Food. Inter J of Electrochemical.Sci. 6 222-230

lxxx. Stahl T1, Hasan Taschan2 and Hubertus Brunn3 (2011) Aluminum content of selected foods and food Products.. Environmental Sciences Europe 2011,23:37

lxxxi. Stahl T11, Falk S2, Rohrbeck A2, Georgian S2, Herzog C1, Wiegand A1, Hotz S3, Boschek B4, Zorn H³, Brunn H5.(2017). Migration of aluminum from food contact materials to food-a health risk for consumers? Part I of III: exposure to aluminum, release of aluminum, tolerable weekly intake (TWI), toxicological effects of aluminum, study design, and methods. Environ Sci Eur. (2017a);29(1):19. doi: 10.1186/ s12302-017-0116-y. Epub 2017 Apr 12

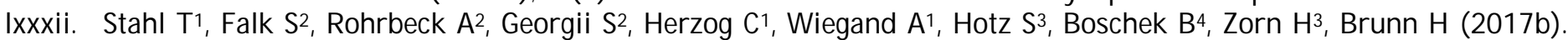
Migration of aluminum from food contact materials to food-a health risk for consumers? Part II of III: migration of aluminum from drinking bottles and moka pots made of aluminum to beverages. Environ Sci Eur. 2017;29(1):18. doi: 10.1186/ s12302-017-0118-9.

lxxxiii. Stahl, T., Falk, S., Rohrbeck, A., Georgii, S., Herzog, C., Wiegand, A., Hotz, S., Boschek, B., Zorn, H. and Brunn, H., (2017c). Migration of aluminum from food contact materials to food-a health risk for consumers? Part III of III: migration of aluminum to food from camping dishes and utensils made of aluminum. Environmental Sciences Europe, 29(1), p.17.

lxxxiv. Thomas, B., Roughan, J. A., Watters, E. D. (1974). Cobalt, Chromium and Nickel Content of Some Vegetable Food stuffs. J. of Nutr. 25: 771-776

lxxxv. Tilahum, C.O., and Ibrahim D.R., (2001). Heavy Metal Action. Applied Journal Of Basic And Applied Sciences. 4(3): 99120.

lxxxvi. Ukanwa, N.D., 2002. Common materials of cookware: Cooking for engineers (Online). Avaliable at http:// cooking for engineers.com/ article/ 120/ common-materials-of-cookware. [Acesssed, 26 ${ }^{\text {th }}$, August, 2013].

lxxxvii. Veien, N. K., (1989). Nickel dermatitis: Its relationship to food and experimental oral challenge. In: Maibach, H. I., Menne, T. eds Nickel And The Skin Immunology And Toxicology. 3rd eds. CRC Press, Inc. Boca Raton, Florida Pg., 165-178

lxxxviii. Veien, N.K. and Menné, T. (1990). Nickel contact allergy and a nickel-restricted diet. Seminars in Dermatology, 9(39):197-205.

lxxxix. Veríssimo M. I. S., Oliveira J. A. B. P., and Gomes M. T. S. R., (2006). Leaching of Aluminum from cooking pans and food containers. Sensors and Actuators B. 118(1-2): 192-197.

xc. Vrochte, H., Schätzke, M., Dringenberg, E., Wölwer-Rieck, U., Büning-Pfaue, H., (1991). The question of nickel release from stainless steel cooking pots. Z. Ernaehrungswiss. 30: 181.

xci. Waskanli R.M., (2009). Best Reviews for cook wares, Cambridge University press, London. Pp 77-100

xcii. Weidenhamer J.D, aPeter A.KobunskiaGilbertKuepouobRebecca W.CorbinaPerryGottesfeldc Lead exposure from aluminum cookware in Cameroon. Science of The Total Environment. Volume 496, 15 October 2014, Pages 339347.https:/ / doi.org/ 10.1016/j.scitotenv.2014.07.016

xciii. WHO (World Health Organization), 2001 "Safety evaluation of certain food additives and contaminants", WHO Food additives Series 46. Joint FAO/ WHO Expert Committee on Food Additives (2001). Accessed: 4 August, 2014). 
xciv. Wienk KJ, Marx JJM and Beyen A.C 1999. Eur F of Nutrition 1999. The concept of iron bioavailability and its assessment :A review

xcv. Wook, L.C., Miura K., Mori R., and Imura N., (2013) Effects of selenium on mercury-induced renal lesions and on subcellular mercury distribution in rats.Ecotoxicology and Environmental Safety. 5: 351-367.

xcvi. World Health Organization (WHO), (2011). "Recommendations" in guidelines for Drinking water quality, Geneva, Switzerland $4^{\text {th }}$ edn 1: 66-68.

xcvii. World Health Organization (WHO). (2015)Evaluation of Certain Foods Additives and Contaminants (Tweenty-Six Report of the Joint FAO/ WHO Expert Committee on Food Additives). WHO Technical Report series, 1982; No. 683 Geneva. http:/ / apps.who.int/ iris/ bitstream/ 10665/ 41546/ 1/ WHO_TRS_683.pdf. Accessed 05 December 2015.

xcviii. Yaquat. R.R., Kalfnal, U.N., Chtou, P.P., and Koit, H.L. (2000) Determination of heavy metal concentration in six cook wares in India. Annals Foods and Tech. 4(6): 234-245.

xcix. Zarel, P.O. Clarkson, T.W. Magos, G. J., (2007). The toxicology of lead current exposure and clinical manifestation in humans. New England J. 349 (34): $1731^{`}$-1737.

c. Zeo, L.E.P., (2005). The Food For Human Population. Palmer books, Pretoria, South Africa. Pp 82-110. 